\title{
The Effects of Website Design Quality and Service Quality on Repurchase Intention Among Shopee Customers in Jakarta, with Customer Trust as a Mediating Variable
}

\author{
Melissa Priscillia $^{1}$, Herlina Budiono $^{1 *}$, Hendra Wiyanto $^{1}$, Hannes Widjaya $^{1}$ \\ ${ }^{1}$ Faculty of Economics and Business, Universitas Tarumanagara, Jakarta, Indonesia \\ *Corresponding author. Email: herlinab@fe.untar.ac.id
}

\begin{abstract}
This study aimed to analyze the effects of website design quality and service quality on customer trust, in which customer trust is a determinant of repurchase intention. Meanwhile, website design quality and service quality are also the predictors of repurchase intention through customer trust among the Shopee customers in Jakarta. The data collection technique was carried out using a questionnaire and distributed through online social media. This study used 170 respondents acquired through convenience-sampling technique. Data was analyzed using PLS-SEM. The result of this research is that website design quality and service quality positively affect customer trust, customer trust positively affects repurchase intention, website design quality and service quality positively affect repurchase intention through customer trust as a mediating variable.
\end{abstract}

Keywords: Website Design Quality, Service Quality, Customer Trust, Repurchase Intention

\section{INTRODUCTION}

Over time, technology and information have developed rapidly, one of which is the internet technology. The internet has become an important part in various aspects of life, one of them is in the people's lifestyle due to its ease and practicality. This, of course, becomes the idea of business people to make the internet as a mean of selling and distributing their products online, known as electronic commerce or e-commerce. E-commerce is defined as a commercial transaction that involves value exchange through the digital technology between individuals and other parties [1]. E-commerce has several differences when being compared to traditional business (or traditional commerce). In the traditional trading concept, buyers and sellers will meet directly (direct interaction) in a market, shop, or other places of business [6]. In the concept of ecommerce, the seller and buyer do not meet directly, instead, the meeting of the two parties is bridged by a website in which both parties can make transactions. Whenever the buyer is interested and already certain, then the buyer can buy the product from these sites [6] (Moon, Sultana, \& Nur, 2017) in [2]. The intention to repurchase is one of the important factors in the field of marketing, because repurchase intention is able to increase the company's profitability which is more significant, because the repeat purchases will generate loyal customers [3]. The quality of the website design is one of the factors that can influence repurchase intention. The better the quality displayed on an e-commerce website, the more likely it is that the consumers will repurchase through the website [4] [5]. Service quality is an important aspect to be considered and implemented. According to [6], service quality can determine whether customers will repurchase on the same page in the future. Customer trust is one of the factors that can influence repurchase intentions. In such rapid challenge, Shopee must consider their position and know exactly the things that could make repurchase intention as their strategy among others, in which many competitors are also making improvements in their website design and service quality to increase the customer repurchase intention.

\section{LITERATURE REVIEW}

\subsection{Website Design Quality}

Website quality is defined as "users' evaluations of a website's features meeting users' needs and reflecting overall experience of website" [7]. Wakefield et al. (2004) in K. A. [8] stated the technological aspect of a website such as layout, appearance, and navigation. The method used to measure the quality of a website is based on the perception of the end-users [9]. Someone's evaluation related to the website features is necessary, to determine whether the feature has met the users' needs and reflects the benefits of the website entirely [10]. Website quality can be defined as the extent to which the website's features can meet what the users need [11]. 


\subsection{Service Quality}

Service quality is a non-tangible benefit which is provided to individuals, business practitioners, governments, and other kinds of organization through the performance of various activities or the provision of physical facilities, products, or activities for others. [12] mentioned that perceived service quality is a comprehensive assessment of a service by customer. Service quality is the customers' attitude established by a long-term evaluation of an mcommerce service performance [13]. The overall support delivered by online service provider is measured in terms of assurance, empathy, and responsiveness [14]. Service quality is a complete evaluation by customers about the services from the company [15].

\subsection{Customer Trust}

Customer trust is an expectation of the parties in a transaction with any organization during the service experience [16]. Trust is the willingness of a party to be vulnerable to another party's actions based on the expectation that the other party will conduct a particular action which is important to the trustor, despite of the ability to control the other party [17]. Trust is a customer's belief to rely on the seller to deliver the promised service [18]. Customer trust is also defined as customer's willingness that enables to accept an online transaction according to their positive and negative expectations on future online shopping behaviour [19]. Trust is a firm's willingness to depend on its business partner. It depends on several interpersonal and interorganizational aspects such as perceived competence, integrity, honesty, and benevolence of the firm [20]. Costumer trust is the whole knowledge owned by costumers and all conclusion made by costumers about the object, attribute, and benefit from a product or service [21].

\subsection{Repurchase Intention}

Repurchase intention is an individual's judgment about repurchasing a service, in form of a decision to involve in future activity with a service provider and in what kind this activity will take [22]. [23] mentioned electronic repurchase intention as the repeat intention of Internet shoppers for buying the products or services delivered by a web-based shopping mall. Repurchase intention is the degree of perceptual conviction of a customer to repurchase a particular product or service from a particular vendor [12]. Repurchase intention is the consumer intention to repurchase a product or service offered by online shops after having a positive experience regarding the use of the particular product or service [24]. Therefore, [25] defined electronic repurchase intention as the customers' tendency to browse the website and consider to purchase the products and services on the same online shop and also be committed to the shop.

\section{RESEARCH MODEL AND HYPOTHESES DEVELOPMENT}

\subsection{The Effect of Website Design Quality on Customer Trust}

[26] stated that there is a positive influence of website design quality on trust. Website design quality with high quality provides convenience to consumers that can make them feel confident in browsing these pages. According to [27], trust reflects a party's positive expectations for behavior towards others in the future. A high quality website exposes the vendor's ability and genuine interest in its customers, thus influencing consumer confidence in the company.

$\mathrm{H}_{1}$ : Website Design Quality positive affects Customer Trust.

\subsection{The Effect of Service Quality on Customer Trust}

[28] examined the effects of service quality and trust on customer loyalty, and stated that service quality positively affects customer trust. Customers who believe in vendors will depend on themselves because of the guarantee of good service quality. On the other hand, customers who do not believe in the company, will not depend on themselves, because there is no guarantee of good service quality.

$\mathrm{H}_{2}$ : Service Quality positively affects Customer Trust.

\subsection{The Effect of Customer Trust on Repurchase Intention}

[29] examined the effects of perceived ease-of-use, perceived usefulness, trust, and perceived enjoyment on repurchase intention, and stated that trust has a positive influence on repurchase intention. According to [24], trust is viewed as an important element in building a company's success. Without trust, a company will find it difficult to build long-term relationship with customers. Research conducted by [24] is in line with [25] which stated that customer trust positively affects repurchase intention.

$\mathrm{H}_{3}$ : Customer Trust positively affects Repurchase Intention.

\subsection{Customer Trust mediates the relationship between Website Design Quality and Repurchase Intention}

[2] examined the effects of website design quality and service quality on repurchase intention through trust as a mediating variable, and stated that trust mediates the effects of website design quality and service quality on repurchase intention. [4] stated that the higher the consumer perception 
of an e-commerce website is, the higher the consumer intention to repurchase on the website will be, through the trust they feel.

$\mathrm{H}_{4}$ : Customer Trust positively mediates the relationship between Website Design Quality and Repurchase Intention.

\subsection{Customer Trust mediates the relationship between Service Quality and Repurchase Intention}

[4] examined the relationship between website quality and repurchase intention through the mediation, and stated that website quality affects repurchase intention by increasing or weakening customer satisfaction, customer trust, and customer commitment in online transaction situations. According to [15], the consumers' decision to repurchase relies on the service quality evaluation they receive. If the evaluation exceeds consumer expectations, they will repurchase the service. On contrary, if the evaluation is lower than consumer expectations, the effect will be different.

$\mathrm{H}_{5}$ : Customer Trust positively mediates the relationship between Service Quality and Repurchase Intention.

\subsection{The Effect of Website Design Quality on Repurchase Intention}

[30] examined the effects of electronic word-of-mouth (EWOM) and website quality on customer satisfaction and repurchase intention, and stated that there is a positive effect of website design quality on repurchase intention. Cheung et al., \& Cheung \& Lee (2005) in [31] stated that whenever a website is able to work well, whereas in this case a website can be easily understood and used by customers, the quality of the website can increase customer confidence in the website and the company. Thus, a website that has a good appearance and quality, can reflect that the company also has a good reputation.

$\mathrm{H}_{6}$ : Website Design Quality positively affects Repurchase Intention.

\subsection{The Effect of Service Quality on Repurchase Intention}

[32] examined the influences of service quality and customer satisfaction on repurchase intention, and stated that there is a positive influence of service quality on repurchase intention. The satisfaction level causes customers to have a stronger desire to conduct repeat purchases. The repetition of purchases is made when consumers feel that all expectation is fulfilled so that they have a desire to make the next purchase of the product or service.
$\mathrm{H}_{7}$ : Service Quality positively affects Repurchase Intention.

\section{METHODOLOGY}

This research has a sample consisting of 170 Shopee's customers in Jakarta, who have conducted transactions through Shopee website, by using convenience-sampling technique. The questionnaire was distributed to Shopee customers through online networks via email, social media, and other means of communication. In this research, we used the descriptive research design, because this research was conducted only once. This research uses a questionnaire as research instrument.

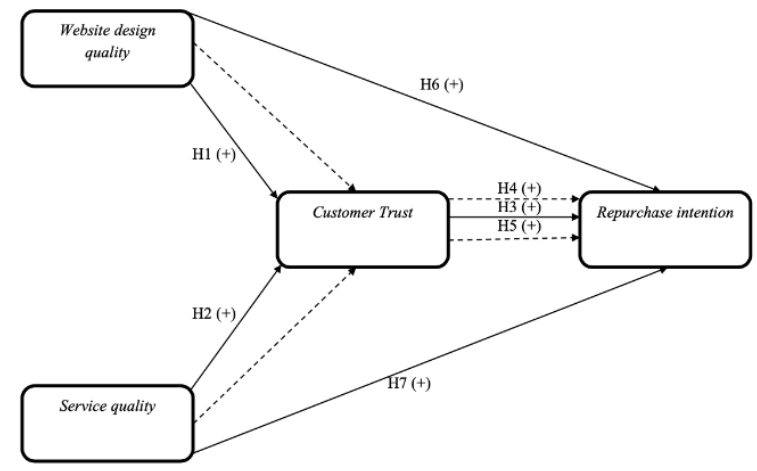

Figure 1 Research Design

\section{DATA ANALYSIS}

Based on gender, the majority of respondents were females $(54.7 \%)$, and the rest were males (45.3\%). Based on age, the majority of respondents aged 31 - 40 years with a total of 65 people $(38.2 \%)$, respondents aged 21-30 years were 63 people $(37.1 \%)$, respondents aged $>40$ years were 28 people $(16.5 \%)$ and respondents aged $<20$ years were 14 people (8.2\%). Among the 170 respondents, most respondents were private employees as many as 56 people $(32.9 \%)$, private employees as many as 55 people $(32.4 \%)$, civil servants as many as 31 people (18.2\%), and 28 students (16.5\%). Among the 170 respondents, the majority of respondents lived in West Jakarta as many as 57 people $(33.5 \%)$ and East Jakarta as many as 57 people (33.5\%), South Jakarta as many as 25 people (14.7\%), Central Jakarta as many as 20 people (11.8\%), and North Jakarta as many as 11 people $(6.5 \%)$. Among 170 respondents, it can be found that respondents who have monthly expenses above Rp. $10,000,000$ were 100 people $(58.8 \%)$, Rp. 5,000,000 Rp. 10,000,000 were 52 people $(30.6 \%)$, and under Rp. $5,000,000$ were 18 people $(10.6 \%)$. Respondents who conducted online shopping above 6 times in a month were 101 people $(59.41 \%), 2$ - 5 times in a month were 63 people $(37.06 \%)$, and once in a month were 6 people $(3.53 \%)$.

The results of the validity test, both convergent validity and discriminant validity, have been carried out by using the Average Variance Extracted (AVE) value greater than 0.5, a loading-factor greater than 0.7, Fornell-Lacker, and cross loadings. In this research, the reliability test had also been 
carried out by measuring the value of composite reliability and the magnitude of the Cronbach's Alpha which is greater than 0.6. $\mathrm{R}^{2}$ was used to measure how much the website design quality and service quality affects customer trust, and how much the website design quality and service quality affects repurchase intention. The $\mathrm{R}^{2}$ for the customer trust as a mediating variable is 0.489 , which means that as much as $48.9 \%$ of variation in the customer trust variable can be recognized through the variations in website design quality and service quality. And then, the remaining $51.1 \%$ variation in the customer trust variable can be explained by other factors not in the scope of this research. Furthermore, there is an $\mathrm{R}^{2}$ value of 0.506 for repurchase intention variable, which means that as much as $50.6 \%$ of variation in this variable can be explained by the variations in the website design quality, service quality, and customer trust. Therefore, the remaining $49.4 \%$ of variation in the repurchase intention variable can be explained by the variables not examined in this research such as price, perceived usefulness, and others. The ability of website design quality and service quality to explain the mediating variable of customer trust can be considered weak. Meanwhile, the ability of website design quality and service quality to explain repurchase intention is fairly moderate. Furthermore, the $\mathrm{Q}^{2}$ test result for customer trust shows a value of 0.410 and for repurchase intention of 0.433 , which means that the predictive relevance $\left(Q^{2}\right)$ value in this research is greater than 0 (zero).

Table 1 Path Coefficients

\begin{tabular}{|l|c|}
\hline \multicolumn{1}{|c|}{ Variable } & $\begin{array}{c}\text { Path } \\
\text { Coefficient }(\beta)\end{array}$ \\
\hline $\begin{array}{l}\text { Website Design Quality } \longrightarrow \\
\text { Customer Trust }\end{array}$ & 0.318 \\
\hline $\begin{array}{l}\text { Service Quality } \longrightarrow \text { Customer } \\
\text { Trust }\end{array}$ & 0.462 \\
\hline $\begin{array}{l}\text { Customer Trust } \longrightarrow \text { Repurchase } \\
\text { Intention }\end{array}$ & 0.711 \\
\hline $\begin{array}{l}\text { Website Design Quality } \longrightarrow \text { Repurchase } \\
\text { Customer Trust } \longrightarrow \text { Customer } \\
\text { Intention }\end{array}$ & 0.226 \\
\hline $\begin{array}{l}\text { Service Quality } \longrightarrow \text { Rrust } \longrightarrow \text { Repurchase } \\
\text { Intention }\end{array}$ & 0.329 \\
\hline $\begin{array}{l}\text { Website Design Quality } \\
\text { Repurchase Intention }\end{array}$ & 0.226 \\
\hline $\begin{array}{l}\text { Service Quality } \longrightarrow \\
\text { Repurchase Intention }\end{array}$ & 0.329 \\
\hline
\end{tabular}

Source: The Results of Data Analysis using PLS-SEM

Table 2 p-Value Results

\begin{tabular}{|l|c|c|}
\hline \multicolumn{1}{|c|}{ Variable } & t-statistics & p-value \\
\hline $\begin{array}{l}\text { Website Design Quality } \longrightarrow \\
\text { Customer Trust }\end{array}$ & 2.820 & 0.005 \\
\hline $\begin{array}{l}\text { Service Quality } \longrightarrow \\
\text { Customer Trust }\end{array}$ & 4.069 & 0.000 \\
\hline
\end{tabular}

\begin{tabular}{|l|c|c|}
\hline $\begin{array}{l}\text { Customer Trust } \longrightarrow \\
\text { Repurchase Intention }\end{array}$ & 11.408 & 0.000 \\
\hline $\begin{array}{l}\text { Website Design Quality } \longrightarrow \\
\begin{array}{l}\text { Customer Trust } \\
\text { Repurchase Intention }\end{array}\end{array}$ & 2.485 & 0.013 \\
\hline $\begin{array}{l}\text { Service Quality } \longrightarrow \\
\text { Customer Trust } \\
\text { Repurchase Intention }\end{array}$ & 4.396 & 0.000 \\
\hline $\begin{array}{l}\text { Website Design Quality } \longrightarrow \\
\text { Repurchase Intention }\end{array}$ & 2.485 & 0.013 \\
\hline $\begin{array}{l}\text { Service Quality } \\
\text { Repurchase Intention }\end{array}$ & 4.396 & 0.000 \\
\hline \begin{tabular}{l} 
Souce: The Result Daf Analysing \\
\hline
\end{tabular}
\end{tabular}

Source: The Results of Data Analysis using PLS-SEM

\section{DISCUSSION}

The result of the first hypothesis $\left(\mathrm{H}_{1}\right)$ test shows that website design quality has a positive effect on customer trust. This is in line with the research conducted by [26] which stated that website design quality is a positive predictor of customer trust. According to Zhou et al. (2009) in [2], the better the design quality on a website of ecommerce business, the more likely the consumers will repurchase during that time. Regarding the result of the second hypothesis test, according to [15], consumers' decision to repurchase is based on the service quality evaluation they receive. If the evaluation exceeds consumer expectations, they will repurchase the service. In contrast, if the evaluation is lower than the consumer expectations, then the effect will be different. The second hypothesis $\left(\mathrm{H}_{2}\right)$ shows that service quality has a positive effect on customer trust. This result is in line with [28]. The maximum service quality provided by Shopee will create more value for customers so that it will make customers feel different from other e-commerce's they experience. Customers will certainly feel happy when Shopee provides the services more than what they receive from other e-commerce's. In addition, customers will feel confident when what they expect is provided by Shopee. Conversely, if the service quality provided by Shopee does not meet their expectations, then they will feel distrustful and this can cause problems for Shopee. Therefore, Shopee is expected to maintain and improve the existing service quality to customers. The third hypothesis $\left(\mathrm{H}_{3}\right)$ shows that customer trust positively affects repurchase intention. The result of this research is in line with [29]. Repurchase intention can certainly occur because of customer trust in a brand. The more customers trust in a brand, the more bonded the customer will be to that brand. Thus, it is very important for Shopee to always prioritize customer trust. When customers match the brand used, they tend to use these services in the future, because customer trust in the brand has been formed. The fourth hypothesis $\left(\mathrm{H}_{4}\right)$ shows that customer trust can mediate the relationship between website design quality and repurchase intention. This result is in line with [4]. When customers feel comfortable with a brand, they tend to be reluctant to switch to another brand. An attractive and good website appearance will cause comfort and pleasure when browsing it. The comfort and pleasure felt by customers 
after browsing the website can lead to trust. This trust can be used as a strong factor for customers to use Shopee's services again in the future continuously, so they are reluctant to move or try other online shopping websites. The result of the fifth hypothesis $\left(\mathrm{H}_{5}\right)$ test shows that customer trust can mediate the relationship between service quality and repurchase intention. Thus, this result is in line with [6]. In increasing repurchase intention, Shopee must improve the services provided so that customers feel for themselves about their experience after shopping at Shopee. After making a transaction, customers will definitely assess the services provided by Shopee. There are only 2 ratings, namely good or bad. A good assessment will generate trust in Shopee so that it can generate customer repurchase intention. Conversely, when a customer gives a bad rating, the customer will not trust Shopee and will not shop again in the future. The result of the sixth hypothesis $\left(\mathrm{H}_{6}\right)$ test concludes that website design quality positively affects repurchase intention. Hence, this result is in line with [30]. E-commerce or online stores must pay attention to their website design quality and must comply with their perceptions so that the customer will make a repurchase through the website. Frequently, customers do not get sufficient information from the website appearance, thus Shopee is expected to be able to maintain and improve its website quality, which is already good. The result of the seventh hypothesis test $\left(\mathrm{H}_{7}\right)$ shows that service quality positively affects repurchase intention. So, this finding is in line with [32]. Service quality is an significant factor in influencing repurchase intention. Shopee's reliability in providing services in responding to consumer complaints can make customers make repeat purchases, become loyal to the company, and will recommend Shopee to others.

\section{CONCLUSION}

Based on data analysis that has been conducted, the conclusion is that website design quality and service quality positively and directly affect repurchase intention, as well as positively and indirectly affect repurchase intention as mediated by customer trust. This study has some limitations, namely the number of samples studied is still limited, namely 170 respondents, the sample is still limited to Jakarta area, the variables studied are still limited to website design quality, service quality, customer trust, and repurchase intention. Some suggestions for further research are using a greater sample size, expanding the scope of the sample criteria, and adding more variables or replacing insignificant variables with those that have a greater influence on repurchase intention, in addition to the variables used in this research. Website design quality and service quality have very important roles in the repurchase intention of Shopee's customers. The higher the level of satisfaction with the quality of the website and services provided by a brand is, the more bonded the customer is to the brand. Website design quality and service quality can occur, because there is a pleasant experience faced by customers when they get good services. Once the customer is satisfied with what is provided and matches the brand used, the customer will tend to re-use the service in the future. Customer trust plays the most important role in mediating the relationship between website design quality and repurchase intention, as well as between service quality and repurchase intention, among the Shopee's customers. Researchers suggest that Shopee must maintain consumer trust by paying attention to and improving the appearance of its website, so that these products and / or services are increasingly believed to have good performance by customers, resulting in positive consumer attitudes towards a brand, thus they have the desire to make repurchase in the future.

\section{REFERENCES}

[1] Laudon, K. C., \& Traver, C. G. (2017). E-Comerce 2016 business, tecnology, society (12th ed.). England: British Library Cataloguint-in.

[2] Wilson, N. \& Keni. (2018). Pengaruh Website Design Quality dan Kualitas Jasa terhadap Repurchase Intention: Variabel Trust sebagai Variabel Mediasi. Jurnal Manajemen dan Pemasaran Jasa, 11(2), 291310.

[3] Goh, S. K., Hak, M.F.A., Tee, P. L. (2016). Determinants of Smartphone Repeat Purchase Intention Among Malaysians: A Moderations Role of Social Influence and a Mediating Effect of Consumer Satisfaction. Internal Review of Management \& Marketing, 6(4), 993-1004.

[4] Shin, J. I., Chung, K. H., Oh, J. S., \& Lee, C. W. (2013). The effect of site quality on repurchase intention in Internet shopping through mediating variables: The case of university students in South Korea. International Journal of Information Management, 33(3), 453-463.

[5] Tandon, U., Kiran, R., \& Sah, A. N. (2017). Customer Satisfaction as Mediator Between Website Service Quality and Repurchase Intention: An Emerging Economy Case. Service Science, 9(2), 106120.

[6] Zhou, T., Lu, Y., \& Wang, B. (2009). The Relative Importance of Website Design Quality and Service Quality in Determining Consumers' Online Repurchase Behavior. Information Systems Management, 26(4), 327-337.

[7] Aladwani, A., \& Palvia, P. (2002). Developing and Validating an Instrument for Measuring User Perceived Web Quality. Information and Management, 39(6), 467-476. 
[8] Bahari, K., A., Abdullah, D., \& Kamal, S. B. M. (2018). The Influence of Hotel Website Design Quality, Perceived Ease Of Use and Perceived Usefulness on Loyalty Intention. The Turkish Online Journal of Design, Art and Communication - TOJDAC, 701-710.

[9] Barnes, S., J., \& Vidgen, R.T. (2002). Assessing ECommerce Quality with WebQual: An Evaluation of the Usability, Information Quality, and Interaction Quality of Internet Bookstores. Journal of Electronic Commerce Research, 3, 114-127.

[10] Alhabsyi, S., \& Mardhiyah, D. (2018). The Influence of Website Trust on Recommendation Adoption and Word-of-Mouth Communication: Study on TripAdvisor Website. International Conference of Organizational Innovation, 1301-1313.

[11] Mohamed, H. A. E. S., \& Al-Azab, M. R. (2017). Exploring Key Factors That Influence Consumer Trust in Airline Websites. Journal of Association of Arab Universities for Tourism and Hospitality, 14(1).

[12] Adekunle, S., A., \& Ejechi, J. O.

(2018). Modelling Repurchase Intention Among Smartphones Users in Nigeria. Journal of Modelling in Management, 13(4),794-814.

[13] Phuong, N. N. D., \& Trang, T. T. D. (2018). Repurchase Intention: The Effect of Service Quality, System Quality, Information Quality, and Customer Satisfaction as Mediating, Marketing and Branding Research 5 (2018), 78-91.

[14] Liang, C. -J., \& Chen, H. -J. (2009). A study of the impacts of website quality on customer relationship performance. Total Quality Management \& Business Excellence, 20(9), 971-988.

[15] Leonnardo \& Thung, F. (2017). The Relationship Of Service Quality, Word-of-Mouth, And Repurchase Intention in Online Transportation Services. (JPMNT) Journal of Process Management-New Technologies, International, 5(4), 30-40.

[16] Upamannyu, N. K., Gulati, C., Chack, A., \& Kaur, G. (2015). The Effect of Customer Trust on Customer Loyalty and Repurchase Intention: The Moderating Influence of Perceived CSR. International Journal of Research in IT, Management and Engineering, 5(4).

[17] Trivedi, S., K., \& Yadav, M. (2018). Predicting online repurchase intentions with e-Satisfaction as mediator: a study on Gen Y. Role: A PLS Approach of M-Commerce Ride Hailing Service in Vietnam. Marketing and Branding Research, 5, 78-91.
[18] Chinomona., R. (2013). Brand Service Quality, Satisfaction, Trust and Preference as Predictors of Consumer Brand Loyalty in the Retailing Industry. Mediterranean Journal of Social Sciences, 4(14).

[19] Razak, N., S., A., Marimuthu, M., Omar, A., \& Mamat, M. (2014). Trust and Repurchase Intention on Online Tourism Services among Malaysian Consumers. Procedia - Social and Behavioral Sciences, 130, 577 582.

[20] Kotler, P., \& Keller, K. L (2016) Marketing Management, 15th Edition, Pearson Education, Inc.

[21] Mowen, J. C., \& Minor, M. (2002) Perilaku Konsumen. Jakarta: Erlangga.

[22] Chen, C., C., V., \& Chen, C.-J. (2017). The role of customer participation for enhancing repurchase intention. Management Decision, 55(3), 547-562.

[23] Nilsson., J., \& Olle Wall, O. (2017). Online customer experience, satisfaction and repurchase intention for online clothing retailing. Master of Science in Marketing and Consumption, 1-22.

[24] Setyorini, R., \& Nugraha, R. P. (2016). The Effect of Trust Towards Online Repurchase Intention with Perceived Usefulness as An Intervening Variable: A Study on KASKUS Marketplace Customers. The Asian Journal of Technology Management, 9(1), 1-7.

[25] Wijaya, R., Farida, Naili., \& Andriyansyah. (2018). Determinants of Repurchase Intentions at Online Stores in Indonesia. International Journal of EBusiness Research, 14(3).

[26] Tatang, M., \& Mudiantono. (2017). The Impact of Website Design Quality, Service Quality, and Enjoyment on Repurchase Intention through Satisfaction and Trust (A Case of Zalora.co.id). Diponegoro Journal of Management, 6(4), 1-11.

[27] Pramana, I. G. Y., \& Ni Made Rastini, N. M. (2016) Pengaruh Kualitas Pelayanan Terhadap Kepercayaan Nasabah dan Loyalitas Nasabah Bank Mandiri Cabang Veteran Denpasar Bali. E-Jurnal Manajemen Unud, 5(1), 706-733.

[28] Nurhadi \& Azis, A. (2018). Pengaruh Kualitas Pelayanan Terhadap Kepercayaan dan Kesetiaan Konsumen. Jurnal Economia. 14(1).

[29] Puspitasari, I., \& Briliana, V. (2017). Pengaruh Perceived Ease-of-Use, Perceived Usefulness, Trust dan Perceived Enjoyment Terhadap Repurchase Intention 
(Studi Kasus Pada Website Zalora Indonesia). Jurnal Bisnis dan Akuntansi, 19(2) 171-182.

[30] Tandon, A., Aakash, A., \& Aggarwal, A. G.

(2020). Impact of EWOM, website quality, and product satisfaction on customer satisfaction and repurchase intention: moderating role of shipping and handling. International Journal of System Assurance Engineering and Management. 1-8.

[31] Bernarto, I., Wilson, N., \& Suryawan, I.N. (2019). Pengaruh Website Design Quality, Service Quality,

Trust dan Satisfaction Terhadap Repurchase Intention (Studi Kasus: tokopedia.com). Jurnal Manajemen Indonesia, 19(1), 80-90.

[32] Wiradarma, I. W. A., \& Respati, N. N. R. (2020). Peran Customer Satisfaction Memediasi Pengaruh Service Quality terhadap Repurchase Intention pada Pengguna Lazada Di Denpasar. E-Jurnal Manajemen, 9(2), 637-657. 